\title{
Transport Kinetics of Amino Acids across the Resting Human Leg
}

\author{
Kent Lundholm," Klas Bennegård, ${ }^{*}$ Helen Zachrisson, * Fredrik Lundgren, * Elisabeth Edén," \\ and Anne-Charlotte Möller-Loswick ${ }^{*}$ \\ Departments of Surgery I* and Anaesthesiology II, University of Gothenburg, Sahlgrenska Hospital, Gothenburg, Sweden
}

\begin{abstract}
Flux rates of amino acids were measured across the leg after an overnight fast in resting human volunteers. A balanced amino acid solution was, after a primed infusion, continuously infused for $2 \mathrm{~h}$ at each of three step-wise and increasing rates corresponding to $8.3,16.7,33.2 \mathrm{mg} \mathrm{N} / \mathrm{kg}$ per $\mathrm{h}$ that were equivalent to $0.2,0.4,0.8 \mathrm{~g} \mathrm{~N} / \mathrm{kg}$ per $\mathrm{d}$. Flux of amino acids across the leg was compared with the flux of glucose, glycerol, lactate, free fatty acids, and oxygen. The size of the muscular tissue pool of amino acids was measured. Whole body amino acid oxidation was estimated by means of the continuous infusion of a ${ }^{14} \mathrm{C}$-labeled mixture of amino acids.
\end{abstract}

Arterial steady state levels were obtained for most amino acids within $\mathbf{3 0}$ to $\mathbf{4 5}$ min after the primed constant infusion. Leg flux of amino acids switched from a net efflux after an overnight fast to a balanced flux between infusion rates corresponding to 0.2-0.4 g N/kg per d. At $0.8 \mathrm{~g}$ N/kg per d essentially all amino acids showed uptake. The infusion of amino acids stimulated leg uptake of glucose and lactate production and decreased FFA release. Oxygen uptake and leg blood flow increased significantly with increased infusion of amino acids. There was significant variability in transport rate among individual amino acids. Branched chain amino acids showed rapid transport and methionine slow transport rate. Only small changes in the muscle tissue concentration of certain amino acids were registered after $6 \mathrm{~h}$ of amino acid infusion despite uptake for several hours. When amino acids were infused at a rate corresponding to $0.8 \mathrm{~g} \mathrm{~N} / \mathrm{kg}$ per $\mathrm{d}$, the leg uptake of amino acids was $6 \%$ and the simultaneous whole body oxidation of infused amino acids was $\sim 10 \%$. Net uptake of leucine across the leg per hour was $62 \%$ of the muscle pool of free leucine when amino acids were infused at a rate corresponding to $0.4 \mathrm{~g}$ $\mathrm{N} / \mathrm{kg}$ per $\mathrm{d}$. Multiple regression analysis showed that the arterial concentration of an amino acid was the most important factor for uptake, more so than insulin concentration and blood flow.

It is concluded that leg exchange of amino acids is large enough to rapidly change the pool size of the amino acids in skeletal muscle, if not counter-regulated by changes in rates of protein synthesis and degradation. Estimates of the capacity for protein synthesis and transfer RNA acceptor sites in muscles agree in order of magnitude with the net uptake of amino

Address correspondence to Dr. Lundholm, Department of Surgery I, Sahlgrenska Hospital, S-413 45, Gothenburg, Sweden. 1987.

Received for publication 30 May 1986 and in revised form 3 March

J. Clin. Invest.

(C) The American Society for Clinical Investigation, Inc.

0021-9738/87/09/0763/09 \$2.00

Volume 80, September 1987, 763-771 acids at high infusion rates of amino acids. Therefore, measurements of the balance of tyrosine, phenylalanine, and particularly methionine at steady state may reflect net balance of proteins across skeletal muscles even in short-time experiments.

\section{Introduction}

We have recently reported that malnourished patients with and without cancer, who received nasogastric tube feeding, were in positive energy and nitrogen balance (1). However, even after a 2-wk period of enteral nutrition we found that most patients remained in negative amino acid balance across the leg even in the fed state, in spite of the fact that the balance of glucose and FFA across the leg indicated a positive energy balance (2). Such results emphasize a discrepancy between energy and protein balance in peripheral tissues during clinical nutrition as well as between whole body nitrogen balance and amino nitrogen balance in some peripheral compartments.

Although these studies were carried out on hospitalized patients (but not bedridden), such observations inevitably raise questions whether conventional nutritional therapy is insufficient to maintain and replenish lean body mass. Conversely, the results may indicate a more general deficiency in resynthesizing skeletal muscle proteins in malnourished patients which is perhaps related to the underlying disease. Irrespective, prior results show that such patients cannot improve lean body mass on a feeding therapy that is supposed by medical practice to be sufficient for resynthesis of lean tissues. Our observation may partly explain why nutritional support to hospitalized patients often fails to increase lean body mass, but not the replenishment of subcutaneous fat.

Modern artificial nutrition must be able to support the resynthesis of peripheral tissue proteins, particularly skeletal muscles. The most simple prerequisite of this is a positive amino acid balance. Therefore, the purpose of this study was to examine kinetics of amino acids and regulating factors for positive amino acid balance across resting peripheral tissues. For this purpose, the human leg has been used, which contains a considerable portion of the lean body mass in the body.

\section{Methods}

Patients. 11 healthy males without medication or a history of diabetes were investigated before surgery for uncomplicated inguinal hernia. They had all been weight stable for at least 1 yr before the examinations. Their body weight was $79 \pm 3 \mathrm{~kg}$ and height $179 \pm 3 \mathrm{~cm}$. Body weight index was $1.02 \pm 0.04$. Body potassium was $3,650 \pm 200 \mathrm{mmol}$ and body potassium index $0.96 \pm 0.04$. Plasma albumin was $40 \pm 3 \mathrm{~g} /$ liter, triceps skinfold $8.7 \pm 0.7 \mathrm{~mm}$, and mid-arm circumference was $30.1 \pm 0.9 \mathrm{~cm}$. All patients had normal body temperature. We regard these patients as healthy volunteers. They all had normal hemoglobin concentration ( $153 \pm 4 \mathrm{~g} /$ liter), sedimentation rate of erythrocytes $(7 \pm 1$ $\mathrm{mm} / \mathrm{h}$ ), normal liver function enzyme test, and normal serum electrolytes and creatinine. Informed consent was obtained from all individ- 
uals and the study protocol was approved by the Ethical Committee, University of Gothenburg.

Investigative procedures. All metabolic studies started in the morning after an overnight fast (12-14 h) with the patients at rest in the bed. Flux of amino acids, glucose, glycerol, lactate, and FFA were measured in relationship to oxygen uptake across the leg in the fasted state in eight of the volunteers. Catheters were inserted in the radial artery and in the femoral vein $1 \mathrm{~h}$ before the start of the investigation. The patency of the catheter was achieved by injections of saline after blood sampling. A balanced solution of amino acids (Vamin N; KabiVitrum, Stockholm, Sweden) was then infused as a primed constant infusion at rates corresponding to $0.2,0.4$, and $0.8 \mathrm{~g} \mathrm{~N} / \mathrm{kg}$ per $\mathrm{d}$ for $2 \mathrm{~h}$ at each level. The infusion started with a monoexponentially primed infusion as described by DeFronzo (3) for insulin infusion to rapidly reach stable arterial levels of amino acids (Fig. 1). The arterio-venous (A-V) difference of amino acids was measured during the last $15-\mathrm{min}$ period of $2 \mathrm{~h}$ at each steady state level (4). Leg blood flow was measured at rest and at each infusion level by a strain-gauge plethysmograph (2). Flux is determined as the $\mathrm{A}-\mathrm{V}$ difference multiplied by blood flow. Blood flow values (milliliters per minute per $100 \mathrm{ml}$ ) were converted to milliliters per minute per $100 \mathrm{~g}$ leg tissue assuming that leg tissue has a specific activity close to one $(1,2)$. This conversion is useful when comparing leg metabolism with whole body metabolism.

At the highest level of infusion $(0.8 \mathrm{~g} \mathrm{~N} / \mathrm{kg}$ per d) blood flow was also measured in five patients by the cardio-green dilution technique as described by Jorfeldt and Wahren (5). An additional three volunteers were subjected to a step-wise infusion with the amino acid solution labeled with a mixture of ${ }^{14} \mathrm{C}$-amino acids of known specific radioactivity. These individuals were infused according to the same protocol as used for the other eight volunteers but flux measurements were done only at the infusion rate of $0.8 \mathrm{~g} \mathrm{~N} / \mathrm{kg}$ per d. Simultaneously, whole body energy expenditure was measured and expired ${ }^{14} \mathrm{CO}_{2}$ was trapped in potassium hydroxide $(0.72 \mathrm{~mol} / \mathrm{liter})$ over $30 \mathrm{~min}$ as described elsewhere (6). The percentage oxidation of the infused labeled amino acid solution was measured from the appearance of radioactivity in the expired carbon dioxide and measured as described for the oxidation rate of tyrosine (6), assuming that $18 \%$ of the labeled carbon dioxide was retained in the bicarbonate pool. Muscle needle biopsies (quadriceps) were taken before and during infusions in five of the eight volunteers during step-wise increased infusion. The tissue content of free amino acids was measured after extraction of the free amino acids by methanol.

Biochemical measurements. Whole blood was immediately precipitated by perchloric acid at a final concentration of $1.4 \mathrm{~mol} / \mathrm{liter}$. Proteins were discarded after centrifugation. The supernatant was neutralized to $\mathrm{pH} 7.4$ by the addition of $3.6 \mathrm{~mol} / \mathrm{liter}$ potassium hydroxide. The amino acids were separated by means of high pressure liquid chromatography using a $C_{18} \mu \mathrm{m}$ Bonda-pak column and precolumn derivatization of amino acids with $O$-phthalaldehyde in an automatic sample injector (7). Eight samples were run over night with a standard before and after each fourth sample. Parafluorophenylalanine (P-PHE) was used as the internal standard in each sample. P-PHE was added in a known concentration to each sample of whole blood before precipitation and correction with regard to all the amino acids in blood was done. The area under the curve of the amino acids was integrated using an automatic computer procedure (Waters Assoc., Div. of Millipore Corp., Milford, MA). According to a chromatogram of all standard amino acids of known concentration, the coefficient of variation for measurements each day of the standard amino acid (P-PHE) over six following weeks was $4.1 \pm 0.2 \%$ based on 47 chromatograms. When 10 standards were analyzed consecutively the variation coefficient was between 2 and $4 \%$ in repeated experiments.

Derivatization with $O$-phthalaldehyde does not give any derivate of secondary amines. Therefore, values of proline are not obtained. In

1. Abbreviations used in this paper: A-V, arterio-venous; P-PHE, parafluorophenylalanine. addition, cysteines are not derivatized under these conditions and are therefore not reported. Threonine and glycine do not separate with a linear gradient of acetonitrile at $25^{\circ} \mathrm{C}$ as used in this system and concentration of the two amino acids are given together. Values of tryptophan are not reported, since difficulties to integrate the peaks in some chromatograms were observed.

Blood gases were measured according to the manufacturer's recommendation in a Radiometer 2, Acid Base Laboratories, Copenhagen, Denmark. Insulin was measured in plasma with a radioimmunoassay (Phadebas) from Pharmacia Fine Chemicals, Uppsala, Sweden. Glucose, glycerol, and lactate were measured by kits from Boehringer Mannheim Diagnostics, Houston, TX. FFA were quantified according to $\mathrm{Ho}(8)$. All samples were kept at $-70^{\circ} \mathrm{C}$ until analyses were performed.

Clinical tests and nutritional assessment. Hemoglobin concentration, sedimentation rate of blood cells, liver function enzyme tests, serum electrolytes, serum creatinine, and albumin were measured according to standard procedures in our hospital. Nutritional assessment included physical examination and measurement of body weight, height, serum albumin, triceps skinfold, and upper-arm circumference. Body potassium was measured in a total body counter. Body weight index is defined as actual body weight divided by reference weight obtained from healthy individuals living in the same area of Sweden as the study individuals (9). Total potassium index is actual body potassium divided by body potassium in reference patients.

$\operatorname{Vamin} N$. The L-amino acid solution that was used for infusion contained in grams per liter: Gly, 2.1; Asp, 4.1; Glu, 9.0; Ala, 3.0; Arg, 3.3; cystein-cystin, 1.4; His, 2.4; Ile, 3.9; Leu, 5.3; Lys, 3.9; Met, 1.9; Phe, 5.5; Pro, 8.1; Ser, 7.5; Thr, 3.0; Trp, 1.0; Tyr, 0.5; and Val, 4.3.

Statistics. For independent variables the non-parametric MannWhitney U-test was used. Dependent variables were tested by means of Wilcoxon's test for paired differences. A parametric group comparison test was used to evaluate whether metabolic balance differs statistically from zero (10). $P<0.05$ is regarded as a statistically significant difference. Regression lines were evaluated by means of analyses of variance and multiple regressions were calculated by means of a computer program (IDA 800; Luxor AB, Motala, Sweden).

\section{Results}

Arterial concentrations of the sum of all amino acids reached stable values between 30 and $45 \mathrm{~min}$ after the start of the primed constant infusion, as shown in Fig. 1. Most of the individual amino acids showed similar kinetics as the sum of all amino acids (results not shown). It was therefore assumed that all samples were taken at steady state levels between 115 and $120 \mathrm{~min}$ after the start of constant infusion.

Table I summarizes the mean arterial concentration of individual amino acids at fasting and at steady state levels during infusion. The concentration of most amino acids increased significantly when compared with the concentration at the preceeding steady state level. Glutamine, arginine, asparagine, and ornithine did not show such a step-wise increase. Of these four amino acids, only arginine was infused.

Table II summarizes the A-V difference and flux rates across the leg of individual amino acids at fasting and during infusion at steady state. Alanine and glutamine accounted for $70 \%$ of the amino nitrogen that was released at fast. Glutamic acid was taken up and ornithine was at balance during the fast. All the other amino acids were released to a significant extent at fast. The infusion of $0.2 \mathrm{~g} \mathrm{~N} / \mathrm{kg}$ per $\mathrm{d}$ and $0.4 \mathrm{~g} \mathrm{~N} / \mathrm{kg}$ per d resulted in balances that were not statistically different from zero, while the infusion of $0.8 \mathrm{~g} \mathrm{~N} / \mathrm{kg}$ per $\mathrm{d}$ gave a significant uptake of most amino acids. The balances of alanine and glutamine were negative at all infusion rates although glutamine 


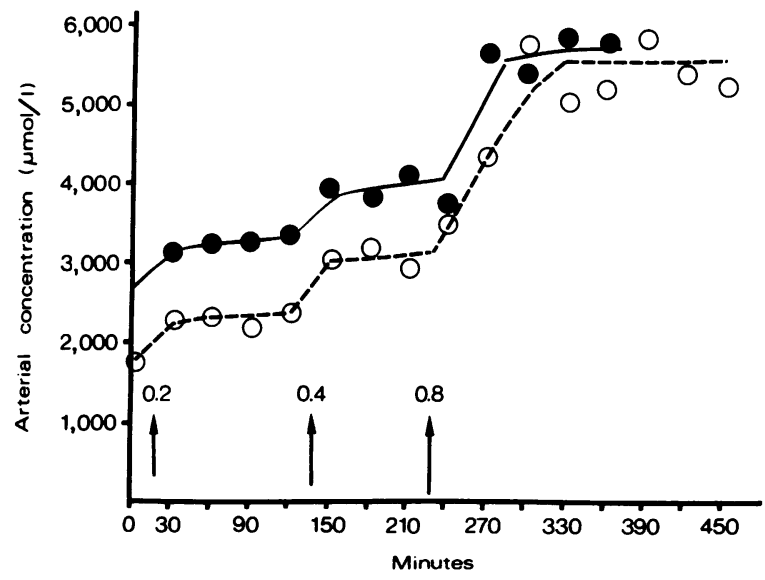

Figure 1. Arterial concentrations (conc) of the sum of all amino acids in whole blood during step-wise increased infusion of a balanced amino acid solution corresponding to $0.2,0.4$, and $0.8 \mathrm{~g} \mathrm{~N} / \mathrm{kg}$ per d. Results are from two individuals.

release was not statistically different from zero at the highest infusion. Asparagine showed a significant release up to $0.4 \mathrm{~g}$ $\mathrm{N} / \mathrm{kg}$ per $\mathrm{d}$ and the balance of threonine-glycine was negative at $0.2 \mathrm{~g} \mathrm{~N} / \mathrm{kg}$ per $\mathrm{d}$ and continued to show numerical negative values, although they were not statistically different from zero balance at 0.4 and $0.8 \mathrm{~g} \mathrm{~N} / \mathrm{kg}$ per $\mathrm{d}$.

Table III summarizes insulin levels, oxygen uptake, and blood flow in relationship to arterial concentrations and bal-

Table I. Arterial Concentrations of Amino Acids

\begin{tabular}{lcccc}
\hline $\begin{array}{l}\text { Amino } \\
\text { acids }\end{array}$ & 0 & 0.2 & 0.4 & 0.8 \\
\hline Ala & $273 \pm 13$ & $333 \pm 14^{*}$ & $376 \pm 17^{\ddagger}$ & $474 \pm 20^{*}$ \\
Gln & $530 \pm 32$ & $562 \pm 37$ & $479 \pm 68$ & $563 \pm 27$ \\
Glu & $197 \pm 16$ & $249 \pm 12^{*}$ & $332 \pm 30^{\ddagger}$ & $565 \pm 39^{*}$ \\
Val & $227 \pm 12$ & $325 \pm 14^{*}$ & $505 \pm 26^{*}$ & $841 \pm 32^{*}$ \\
Leu & $125 \pm 9$ & $205 \pm 10^{*}$ & $343 \pm 25^{*}$ & $575 \pm 25^{*}$ \\
Ile & $53 \pm 2$ & $112 \pm 4^{*}$ & $208 \pm 15^{*}$ & $370 \pm 20^{*}$ \\
Tyr & $89 \pm 5$ & $123 \pm 9^{\ddagger}$ & $163 \pm 12^{\ddagger}$ & $198 \pm 13^{*}$ \\
Phe & $43 \pm 2$ & $97 \pm 3^{*}$ & $172 \pm 15^{*}$ & $298 \pm 12^{*}$ \\
Met & $16 \pm 1$ & $33 \pm 1^{*}$ & $53 \pm 4^{*}$ & $84 \pm 4^{*}$ \\
Asp & $118 \pm 10$ & $136 \pm 8^{\ddagger}$ & $162 \pm 18$ & $217 \pm 14^{*}$ \\
Asn & $125 \pm 18$ & $123 \pm 18$ & $130 \pm 19$ & $115 \pm 25$ \\
Ser & $136 \pm 5$ & $214 \pm 11^{*}$ & $314 \pm 14^{*}$ & $466 \pm 28^{*}$ \\
His & $85 \pm 7$ & $107 \pm 8^{*}$ & $128 \pm 10^{\ddagger}$ & $159 \pm 15^{\ddagger}$ \\
Thr-Gly & $452 \pm 13$ & $535 \pm 18^{*}$ & $608 \pm 27^{\ddagger}$ & $716 \pm 34^{\ddagger}$ \\
Arg & $55 \pm 1$ & $60 \pm 2$ & $70 \pm 6$ & $84 \pm 7$ \\
Tau & $267 \pm 15$ & $310 \pm 25^{\ddagger}$ & $352 \pm 34^{\ddagger}$ & $408 \pm 28$ \\
Orn & $113 \pm 13$ & $119 \pm 11$ & $132 \pm 5$ & $167 \pm 12^{*}$ \\
Lys & $180 \pm 8$ & $231 \pm 13^{*}$ & $274 \pm 18^{\ddagger}$ & $332 \pm 17^{\ddagger}$ \\
Total & $3,088 \pm 99$ & $3,874 \pm 134^{*}$ & $4,799 \pm 259^{*}$ & $6,639 \pm 265^{*}$ \\
& & & &
\end{tabular}

In whole blood (micromoles per liter) after an overnight fast (0), and at steady state during infusion of $0.2,0.4$, and $0.8 \mathrm{~g} \mathrm{~N} / \mathrm{kg}$ per $\mathrm{d}$ of an amino acid solution. There were eight subjects. Mean \pm SE.

* $P<0.01$ vs. the preceding rate of infusion.

${ }^{\ddagger} P<0.05$ vs. the preceding rate of infusion. ances of glucose, lactate, glycerol, and FFA. Insulin concentrations and oxygen uptake increased significantly only at the highest infusion rate, while blood flow increased at $0.4 \mathrm{~g} \mathrm{~N} / \mathrm{kg}$ per d compared with fasting levels. Arterial concentrations of glucose, glycerol, and FFA were unchanged, while lactate decreased significantly from $0.2 \mathrm{~g} \mathrm{~N} / \mathrm{kg}$ per $\mathrm{d}$ of infusion and on. Glucose uptake increased continuously and reached a significantly increased uptake at $0.4 \mathrm{~g} \mathrm{~N} / \mathrm{kg}$ per $\mathrm{d}$. Glycerol flux was not statistically significantly altered at any amino acid infusion rate, although the A-V difference was at 0.4 and $0.8 \mathrm{~g} \mathrm{~N} / \mathrm{kg}$ per d. FFA release showed a significant decrease between infusion of 0.4 and $0.8 \mathrm{~g} \mathrm{~N} / \mathrm{kg}$ per $\mathrm{d}$. Amino acid infusion resulted in increased lactate release by the leg, yet arterial lactate levels decreased. This suggests that the uptake of lactate by other tissues, most likely the liver, was increased in response to amino acid infusion.

The muscle content of free amino acids at the various infusion rates is shown in Table IV. The muscle free pool of all amino acids was unchanged in spite of $6 \mathrm{~h}$ infusion of amino acids. However, the pool of valine, leucine, isoleucine, phenylalanine, and methionine increased significantly, while that of taurine decreased in five of six patients. The pool of methionine increased, although the change in flux rate across the leg was not statistically significant. Considering the net efflux of amino acids in the fasting state, the time required to decrease the pool size of individual amino acids to zero levels was calculated, provided that the pool was not replenished from net degradation of proteins. Such calculations are shown in Table $\mathrm{V}$. The phenylalanine and methionine pool have the shortest turnover time, in the range of $3 \mathrm{~h}$, while glutamine had $47 \mathrm{~h}$ and serine $123 \mathrm{~h}$ turnover.

In Fig. 2 the relationship between the arterial concentration and the balance of branched chain amino acids are shown. The branched chain amino acids together represented the major component of amino nitrogen uptake. The flux of individual amino acids was, therefore, compared with that of the branched chain amino acids. The slopes for uptake of individual amino acids are shown in Table VI. The slopes were calculated by fitting the data to linear regressions which were tested by analyses of variance. The coefficient of the slopes were then compared statistically as a measure of uptake rate versus the arterial concentration of the amino acid. Lysine and serine had a significantly more rapid uptake than the branched chain amino acids together. Tyrosine, phenylalanine, methionine, histidine, and threonine-glycine had slower uptake. The arterial concentration for zero balance of the individual amino acids was calculated from the regressions in Table VI. These results were for (in micromoles per liter) branched chain, 543; Tyr, 130; Phe, 34; Met, 57; Ser, 133; His, 134; Thr-Gly, 690; Leu, 229; and for sum of all amino acids, 4,123 $\mu$ mol/liter. When these values are compared with fasting values of amino acids, one can obtain an estimate of the magnitude of arterial concentrations of individual amino acids that must be increased in order to switch from negative balance to net uptake. These indexes (times fasting levels) were for: branched chain, 1.3; Tyr, 1.5; Phe, 2.2; Met, 3.6; Ser, 1.0; His, 1.6; and ThrGly, 1.5; the sum of all amino acids was 1.3 .

The percentage uptake of administered amino acids in peripheral tissues was calculated by dividing the infusion rate of individual amino acids (micromoles per kilogram per minute) by the flux across the leg (micromoles per kilogram per minute) at the highest infusion rate $(0.8 \mathrm{~g} \mathrm{~N} / \mathrm{kg}$ per d) for all the 
Table II. A-V Differences* and Flux $(F L)^{\ddagger}$ across the Leg after an Overnight Fast (0) and at Steady State ${ }^{\S}$

\begin{tabular}{|c|c|c|c|c|}
\hline & 0 & 0.2 & 0.4 & 0.8 \\
\hline Ala A-V & $-63 \pm 10^{\prime \prime}$ & $-68 \pm 6^{\| \prime}$ & $-92 \pm 11^{11}$ & $-70 \pm 16^{\prime \prime}$ \\
\hline FL & $-163 \pm 21^{11}$ & $-216 \pm 33^{\prime \prime}$ & $-423 \pm 82^{\prime \prime}$ & $-300 \pm 96^{\prime}$ \\
\hline Gln A-V & $-53 \pm 22^{\prime}$ & $-40 \pm 22$ & $-163 \pm 49^{\prime \prime}$ & $-51 \pm 33$ \\
\hline FL & $-96 \pm 63$ & $-99 \pm 85$ & $-547 \pm 112^{\prime \prime}$ & $-91 \pm 156$ \\
\hline Glu A-V & $29 \pm 5^{\prime \prime}$ & $70 \pm 6^{11}$ & $113 \pm 28^{\prime \prime}$ & $131 \pm 23^{\prime \prime}$ \\
\hline FL & $85 \pm 21^{11}$ & $238 \pm 49^{\prime \prime}$ & $477 \pm 137^{\prime \prime}$ & $526 \pm 123^{\prime \prime}$ \\
\hline Val A-V & $-13 \pm 3^{\prime \prime}$ & $12 \pm 3^{\prime \prime}$ & $32 \pm 17$ & $76 \pm 13^{\prime \prime}$ \\
\hline FL & $-30 \pm 5^{\prime \prime}$ & $40 \pm 14^{\prime}$ & $130 \pm 77$ & $305 \pm 67^{\prime \prime}$ \\
\hline Leu A-V & $-9 \pm 5$ & $3 \pm 2$ & $29 \pm 15$ & $53 \pm 10^{\prime \prime}$ \\
\hline FL & $-28 \pm 14^{\prime}$ & $16 \pm 8$ & $117 \pm 65$ & $216 \pm 56 "$ \\
\hline Iso A-V & $-7 \pm 1^{11}$ & $9 \pm 1^{11}$ & $24 \pm 10^{\prime}$ & $42 \pm 7^{11}$ \\
\hline FL & $-19 \pm 5^{\prime \prime}$ & $31 \pm 6^{\prime \prime}$ & $107 \pm 44^{\prime}$ & $173 \pm 41^{11}$ \\
\hline Tyr A-V & $-4 \pm 6$ & $-3 \pm 3$ & $-3 \pm 6$ & $10 \pm 4^{\prime}$ \\
\hline FL & $-8 \pm 14$ & $-6 \pm 7$ & $10 \pm 26$ & $37 \pm 21$ \\
\hline Phe A-V & $-6 \pm 1^{\prime \prime}$ & $3 \pm 1^{\prime}$ & $10 \pm 8$ & $20 \pm 5^{\prime \prime}$ \\
\hline FL & $-21 \pm 7^{1}$ & $11 \pm 4^{1}$ & $36 \pm 35$ & $79 \pm 28^{\prime}$ \\
\hline Met A-V & $-4 \pm 0.3^{\prime \prime}$ & $-1 \pm 1$ & $0 \pm 3$ & $2 \pm 1$ \\
\hline FL & $-10 \pm 1^{11}$ & $-3 \pm 3$ & $-4 \pm 12$ & $6 \pm 5$ \\
\hline Asp A-V & $-6 \pm 3$ & $6 \pm 6$ & $23 \pm 8^{\prime}$ & $33 \pm 911$ \\
\hline FL & $-14 \pm 10$ & $31 \pm 18$ & $89 \pm 42^{1}$ & $121 \pm 45^{\prime \prime}$ \\
\hline Asn A-V & $-11 \pm 3^{\prime \prime}$ & $-9 \pm 3^{1}$ & $-30 \pm 8^{\prime \prime}$ & $-14 \pm 9$ \\
\hline FL & $-29 \pm 8^{\prime \prime}$ & $-28 \pm 9^{\prime}$ & $-147 \pm 43^{\prime \prime}$ & $-58 \pm 48$ \\
\hline Ser A-V & $-5 \pm 6$ & $22 \pm 4^{\prime \prime}$ & $43 \pm 14^{\prime}$ & $44 \pm 12^{\prime \prime}$ \\
\hline FL & $-4 \pm 13$ & $64 \pm 12^{\prime \prime}$ & $194 \pm 78^{\prime}$ & $170 \pm 57^{\prime}$ \\
\hline His A-V & $-8 \pm 2^{\prime \prime}$ & $-3 \pm 1^{\prime}$ & $0 \pm 4$ & $2 \pm 5$ \\
\hline FL & $-19 \pm 4^{\prime \prime}$ & $-6 \pm 5$ & $-2 \pm 15$ & $2 \pm 19$ \\
\hline Thr-Gly A-V & $-37 \pm 10^{\prime \prime}$ & $-15 \pm 4^{\prime \prime}$ & $-10 \pm 19$ & $-2 \pm 13$ \\
\hline FL & $-97 \pm 20^{\prime \prime}$ & $-44 \pm 18^{\prime}$ & $-63 \pm 69$ & $-24 \pm 63$ \\
\hline $\operatorname{Arg} A-V$ & $-6 \pm 1^{\prime}$ & $-4 \pm 2$ & $-3 \pm 3$ & $2 \pm 2$ \\
\hline FL & $-16 \pm 5^{\prime}$ & $-8 \pm 5$ & $-11 \pm 9$ & $3 \pm 11$ \\
\hline Tau A-V & $-13 \pm 4^{\prime \prime}$ & $-3 \pm 4$ & $-16 \pm 7^{\prime}$ & $1 \pm 3$ \\
\hline FL & $-32 \pm 7^{11}$ & $-3 \pm 14$ & $-84 \pm 32^{\prime}$ & $-3 \pm 15$ \\
\hline Orn A-V & $-3 \pm 4$ & $1 \pm 4$ & $8 \pm 7$ & $6 \pm 6$ \\
\hline FL & $0 \pm 10$ & $8 \pm 13$ & $44 \pm 31$ & $29 \pm 27$ \\
\hline Lys A-V & $-17 \pm 7^{1}$ & $-13 \pm 9$ & $18 \pm 10$ & $16 \pm 8^{\prime}$ \\
\hline FL & $-29 \pm 20$ & $-35 \pm 30$ & $78 \pm 60$ & $63 \pm 37$ \\
\hline Branched A-V & $-28 \pm 7^{\prime \prime}$ & $24 \pm 4^{\prime \prime}$ & $85 \pm 42^{\prime}$ & $171 \pm 29^{\prime \prime}$ \\
\hline $\mathbf{F L}$ & $-33 \pm 27$ & $62 \pm 20^{\prime}$ & $516 \pm 178^{\prime}$ & $769 \pm 152^{\prime \prime}$ \\
\hline Total A-V & $-232 \pm 67^{\prime \prime}$ & $-28 \pm 43$ & $14 \pm 140$ & $301 \pm 96^{\prime}$ \\
\hline FL & $-522 \pm 124^{\prime \prime}$ & $9 \pm 191$ & $3 \pm 593$ & $1,136 \pm 448^{\prime}$ \\
\hline
\end{tabular}

* Micromoles per liter. ${ }^{\ddagger}$ Nanomoles per minute per $100 \mathrm{~g}$. ${ }^{8}$ During infusion of $0.2,0.4$, and $0.8 \mathrm{~g} \mathrm{~N} / \mathrm{kg}$ per $\mathrm{d}$ of an amino acid solution. There were eight subjects. Mean \pm SE. " $P<0.01$ vs. fasted or different from zero balance at fasting. ' $P<0.05$ vs. fasted or different from zero balance at fasting.

subjects. The figures were for individual amino acids in percent of infusion rate: Glu, 146; Val, 139; Leu, 91; Ile, 97; Tyr, 207; Phe, 41; Met, 7; Asp, 66; Ser, 41; His, < 2; Thr-Gly, < 1; and Lys, 39. The results show that $\sim 35 \%$ of the infused amino acid nitrogen were taken up in peripheral tissues and that one leg disposal was $\sim 6 \%$ of the infused amino acids. 
Table III. Arterial Concentration (conc), ${ }^{*} A-V$ Differences, ${ }^{\ddagger}$ and Flux Across the Leg ${ }^{\S}$

\begin{tabular}{|c|c|c|c|c|}
\hline & 0 & 0.2 & 0.4 & 0.8 \\
\hline Glucose conc & $6,039 \pm 105$ & $5,966 \pm 69$ & $5,900 \pm 79$ & $6,466 \pm 208$ \\
\hline Flux & $371 \pm 138$ & $751 \pm 275$ & $1,200 \pm 245^{\prime \prime}$ & $1,814 \pm 698^{\prime}$ \\
\hline$A-V$ & $144 \pm 54$ & $209 \pm 67$ & $274 \pm 36^{\prime \prime}$ & $366 \pm 92^{\prime}$ \\
\hline Lactate conc & $779 \pm 84$ & $597 \pm 61^{11}$ & $500 \pm 30^{\prime \prime}$ & $597 \pm 67^{11}$ \\
\hline Flux & $-160 \pm 129$ & $-685 \pm 103^{\prime \prime}$ & $-697 \pm 123$ & $260 \pm 231^{\prime \prime}$ \\
\hline$A-V$ & $-84 \pm 45$ & $-206 \pm 28^{\prime \prime}$ & $-181 \pm 30^{1}$ & $-102 \pm 48$ \\
\hline Glycerol conc & $65 \pm 9$ & $74 \pm 6$ & $80 \pm 5$ & $70 \pm 6$ \\
\hline Flux & $-136 \pm 32$ & $-139 \pm 33$ & $-159 \pm 67$ & $-66 \pm 37$ \\
\hline$A-V$ & $-45 \pm 8$ & $-37 \pm 5$ & $-30 \pm 911$ & $-21 \pm 9^{\prime \prime}$ \\
\hline FFA conc & $513 \pm 34$ & $474 \pm 29$ & $533 \pm 37$ & $452 \pm 55$ \\
\hline Flux & $-298 \pm 77$ & $-119 \pm 70$ & $158 \pm 163^{\prime \prime}$ & $8 \pm 150^{\prime \prime}$ \\
\hline$A-V$ & $-122 \pm 38$ & $-39 \pm 17^{\prime}$ & $+30 \pm 32^{\prime \prime}$ & $-6 \pm 29^{\prime \prime}$ \\
\hline Insulin conc & $16 \pm 3$ & $18 \pm 3$ & $18 \pm 2$ & $34 \pm 5^{\prime \prime}$ \\
\hline Oxygen flux & $8.5 \pm 1.6$ & $11.0 \pm 1.9$ & $14.1 \pm 3.9$ & $15.5 \pm 3.1^{\| \prime}$ \\
\hline Blood flow & $3.06 \pm 0.58$ & $3.34 \pm 0.57$ & $4.62 \pm 0.57^{\prime \prime}$ & $4.62 \pm 0.78^{\prime \prime}$ \\
\hline
\end{tabular}

* Micromoles per liter. ${ }^{\ddagger}$ Micromoles per liter. $\$$ In relationship to oxygen uptake and leg blood flow after an overnight fast (0) and at steady state during infusion of $0.2,0.4$, and $0.8 \mathrm{~g} \mathrm{~N} / \mathrm{kg}$ per $\mathrm{d}$ of an amino acid solution. There were eight subjects. Mean $\pm \mathrm{SE}$. " $P<0.01 \mathrm{vs.} \mathrm{fasted}$ state. ' $P<0.05$ vs. fasted state.

Table IV. Muscle Content of Amino Acids*

\begin{tabular}{|c|c|c|c|}
\hline & 0 & 0.4 & 0.8 \\
\hline Ala & $4.64 \pm 0.41$ & $4.40 \pm 0.39$ & $5.01 \pm 0.20$ \\
\hline Gln & $22.98 \pm 3.07$ & $20.33 \pm 2.40$ & $22.29 \pm 2.77$ \\
\hline Glu & $5.29 \pm 0.89$ & $4.06 \pm 0.74$ & $4.01 \pm 0.30$ \\
\hline Val & $0.74 \pm 0.07$ & $1.04 \pm 0.07^{\ddagger}$ & $1.74 \pm 0.12^{\ddagger}$ \\
\hline Leu & $0.57 \pm 0.05$ & $0.71 \pm 0.15^{\ddagger}$ & $1.30 \pm 0.07^{\ddagger}$ \\
\hline Ile & $0.29 \pm 0.04$ & $0.49 \pm 0.04^{\ddagger}$ & $0.81 \pm 0.03^{\ddagger}$ \\
\hline Phe & $0.18 \pm 0.03$ & $0.41 \pm 0.04^{\ddagger}$ & $0.74 \pm 0.04^{\ddagger}$ \\
\hline Met & $0.10 \pm 0.02$ & $0.15 \pm 0.02^{8}$ & $0.24 \pm 0.02^{\ddagger}$ \\
\hline Asp & $1.08 \pm 0.27$ & $1.44 \pm 0.53$ & $1.15 \pm 0.50$ \\
\hline Aspn & $0.82 \pm 0.13$ & $0.68 \pm 0.14$ & $0.54 \pm 0.16$ \\
\hline Ser & $1.47 \pm 0.32$ & $1.67 \pm 0.22$ & $2.02 \pm 0.17$ \\
\hline His & $0.61 \pm 0.05$ & $0.62 \pm 0.11$ & $0.60 \pm 0.09$ \\
\hline Thr-Gly & $4.25 \pm 0.36$ & $3.96 \pm 0.32$ & $4.11 \pm 0.38$ \\
\hline Arg-Tyr & $19.12 \pm 1.53$ & $15.95 \pm 2.17$ & $16.70 \pm 4.64$ \\
\hline Tau & $40.98 \pm 2.85$ & $33.32 \pm 2.14^{\ddagger}$ & $36.16 \pm 2.49$ \\
\hline Orn & $0.20 \pm 0.05$ & $0.18 \pm 0.08$ & $0.18 \pm 0.10$ \\
\hline Lys & $1.03 \pm 0.25$ & $0.86 \pm 0.22$ & $1.01 \pm 0.44$ \\
\hline Total & $104.4 \pm 7.4$ & $89.71 \pm 8.01$ & $98.49 \pm 10.27$ \\
\hline $\begin{array}{l}\text { Muscle dry } \\
\text { weight }(m g)\end{array}$ & $9.26 \pm 1.85$ & $6.79 \pm 1.97$ & $8.37 \pm 3.30$ \\
\hline$n$ & 5 & 5 & 4 \\
\hline
\end{tabular}

$n$, Number of patients.

* Nanomoles per milligram lipid free dry weight. After an overnight fast and after $2 \mathrm{~h}$ of infusion of amino acids at $0.2 \mathrm{~g} \mathrm{~N} / \mathrm{kg}$ per $\mathrm{d}$ plus $2 \mathrm{~h}$ at $0.4 \mathrm{~g} \mathrm{~N} / \mathrm{kg}$ per $\mathrm{d}$ and after further $2 \mathrm{~h}$ infusion at $0.8 \mathrm{~g} \mathrm{~N} / \mathrm{kg}$ per $\mathrm{d}$, altogether equalling $6 \mathrm{~h}$ of infusion.

$P<0.01$ vs. fasted state.

${ }^{8} P<0.05$ vs. fasted state.
Values of amino acid uptake across the leg were compared with the estimated whole body oxidation of infused amino acids during a constant infusion of radioactive amino acids in three of the subjects (Table VII). The results show that the immediate oxidation rate of infused amino acid carbons corresponded to $\sim 7-10 \%$ of the infused amino acids.

Table VIII shows multiple regression analysis for phenylalanine balance (A-V balance) versus arterial concentration of phenylalanine, arterial insulin levels, and leg blood flow. The

Table V. Calculated Turnover Time for the Skeletal Muscle Pool of Individual and Soluble Amino Acids*

\begin{tabular}{lc}
\hline & Hours \\
\hline Ala & 9.5 \\
Gln & 47 \\
Val & 8 \\
Leu & 7 \\
Ile & 5 \\
Phe & 3 \\
Met & 3 \\
Asp & 26 \\
Asn & 9 \\
Ser & 123 \\
His & 11 \\
Thr-Gly & 15 \\
Tau & 427 \\
Lys & 12 \\
\hline
\end{tabular}

* The tissue pool (nanomoles per gram) after an overnight fast is divided by the efflux rate (nanomoles per minute per gram) of the amino acid after an overnight fast. 


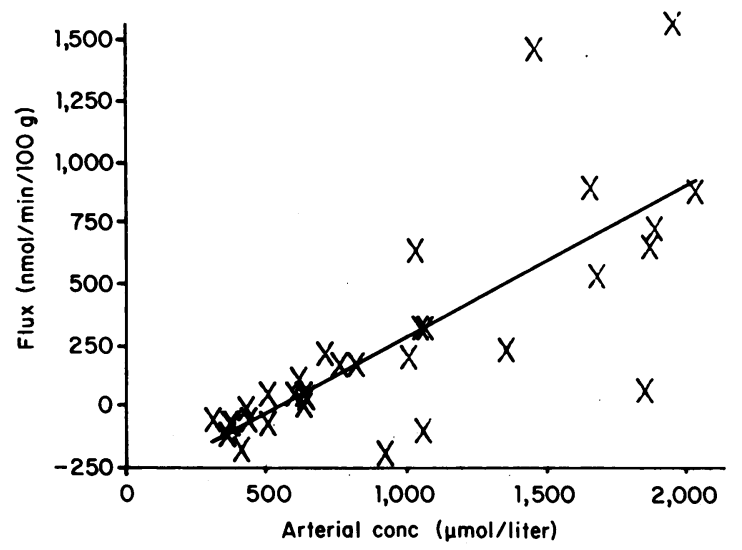

Figure 2. The relationship between arterial concentration and leg exchange of branched chain amino acids. Pooled observations from eight individuals investigated in fasting state and during steady state infusion at $0.2,0.4$, and $0.8 \mathrm{~g} \mathrm{~N} / \mathrm{kg}$ per $\mathrm{d}$ of the amino acid solution. The regression is given in Table VI.

results demonstrate that only the arterial level of phenylalanine had a positive and significant influence on the variance of phenylalanine balance, whereas insulin and blood flow in themselves did not significantly explain the variability in phenylalanine balance. The two together did, however, contribute significantly to the multifactorial analysis. Similar results were obtained for tyrosine and methionine. In a single factor analysis, insulin correlated to the balance of phenylalanine and many other amino acids at the level of $r=0.40-0.45, P<0.05$, but blood flow did not. The transport capacity of amino acids was not limiting for uptake, which was evaluated by calculations of blood clearance of the amino acids such as branched chain, methionine, tyrosine, and phenylalanine across the leg (results not shown). That amino acid uptake was proportional to the arterial concentration can also be seen in Fig. 2 .

\section{Discussion}

This study has evaluated the net balance of blood amino acids across the leg in human adults. Flux of amino acids across the resting leg after an overnight fast was compared to flux at steady state during the constant infusion of increasing quantities of amino acids. Most of the blood amino acids reached steady state levels within 30 to $\mathbf{4 5}$ min after a primed constant infusion of an amino acid solution. Therefore, we believe that a time period of $100 \mathrm{~min}$ was enough to reach steady state in the plasma and blood compartment (4). We have assumed that interstitial amino acids are in rapid equilibrium with the intravascular pool of amino acids.

The ultimate goal of our experiments is to obtain a clinical model to evaluate regional net protein balance. It is obvious that flux measurements of amino acids across the leg do not necessarily give information on protein balance in acute experiments (11). Rapid changes in flux may in theory only reflect changes in the intracellular pool of free amino acids (12). However, seen over time, net balance of amino acids must given predictive information with regard to net protein balance. In a condition of continuous efflux of amino acids, the tissue pool must soon approach a state where amino acid exchanges reflect protein balance. This is illustrated by calculations of the fractional replacement time for the tissue pool of individual amino acids (Table V). Accounting for the efflux rate of methionine from the leg after an overnight fast, it can be calculated that the intracellular pool of methionine should be near zero value within $\mathbf{3} \mathrm{h}$ if not replenished. In this sense, it can be claimed that the intracellular availability of certain amino acids may under some conditions be limiting for protein synthesis, although it is generally recognized that transport rates or the transport capacity of amino acids in themselves is never limiting for protein synthesis. In this study it was confirmed that the transport capacity was not limiting for amino acid uptake. It has been reported that the tRNA pool of amino acids is fully charged, even in starvation (13). The complete charging of tRNA in substrate-deficient conditions and Michaelis constant $\left(K_{\mathrm{m}}\right)$ values in the range of $2-6 \mu \mathrm{M}$ for amino acid acylation of tRNA have been taken to indicate that amino acids are not limiting for protein synthesis (14).

We have reported that the maximum rate of leucine incorporation into proteins is $\sim 50-100 \mathrm{nmol} / \mathrm{min}$ per $100 \mathrm{~g}$ in incubated human muscle tissue (15-19). This value can be compared with the maximum acceptor site (pool-size) for

Table VI. Regressions Calculated from the Arterial Levels of Amino Acids versus Net Balance of Amino Acids at each Level of Steady State*

\begin{tabular}{lllllll}
\hline Amino acids & Regression & $P<$ & $r$ & $\begin{array}{l}\text { Coeff of } \\
\text { the slope }\end{array}$ & $\begin{array}{l}\text { SD } \\
\text { coeff }\end{array}$ & $\begin{array}{l}\text { Total } \\
\text { coeff }\end{array}$ \\
\hline Branched chain & $y=0.6154, x-334$ & 0.01 & 0.76 & 0.6154 & 0.0950 \\
Tyr & $y=0.4934, x-86$ & 0.01 & 0.51 & 0.4934 & 0.1507 & 3.4752 \\
chain amino acids
\end{tabular}

Significance of regressions were tested by analysis of variance. * At fast, at infusion of $0.2,0.4$, and $0.8 \mathrm{~g} \mathrm{~N} / \mathrm{kg}$ per $\mathrm{d}$. Total is the sum of all amino acids. 
Table VII. Whole Body Gas Exchange and Amino Acid Metabolism*

\begin{tabular}{|c|c|c|c|c|c|c|}
\hline Patients & $\mathrm{O}_{2}$ uptake & $\mathrm{CO}_{2}$ production & RQ & $\begin{array}{l}\text { Infusion rate } \\
\text { of AA }\end{array}$ & $\begin{array}{l}\text { Uptake across the } \\
\text { leg of AA }\end{array}$ & $\begin{array}{l}\text { Oxidation of } \\
\text { infused AA }\end{array}$ \\
\hline & $\mu \mathrm{mol} \times \mathrm{min}^{-1}$ & $\mu \mathrm{mol} \times \mathrm{min}^{-1}$ & $\mu \mathrm{mol} \times \mathrm{min}^{-1}$ & $\mu \mathrm{mol} \times \mathrm{min}^{-1}$ & $\mu \mathrm{mol} \times \mathrm{min}^{-1}$ & $\mu \mathrm{mol} \times \mathrm{min}^{-1}$ \\
\hline S.F. & 12,300 & 9,712 & 0.79 & 3,287 & 248 & 321 \\
\hline J.B. & 13,709 & 11,278 & 0.84 & 3,044 & 103 & 207 \\
\hline S.S. & 12,803 & 9,698 & 0.75 & 3,079 & 184 & 309 \\
\hline
\end{tabular}

AA, amino acid. $\quad$ * In three subjects who were infused with a mixture of ${ }^{14} \mathrm{C}$-amino acids to estimate the percentage of infused amino acids being oxidized in relation to flux. For details see Methods.

highly purified leucyl-tRNA, which is in the range of 100-120 $\mathrm{nmol} / 100 \mathrm{~g}$ tissue weight, whereas the maximum capacity for aminoacyl-tRNA synthetase activity (the enzyme) is $\sim 100$ fold higher (20-22). The above values shall be compared with leucine uptake across the leg, which was $216 \pm 25 \mathrm{nmol} / \mathrm{min}$ per $100 \mathrm{~g}$ at the highest infusion rate $(0.8 \mathrm{~g} \mathrm{~N} / \mathrm{kg}$ per $\mathrm{d}$, Table II). Such values, thus, indicate that flux rate of amino acids in vivo is within the order of magnitude for previously estimated capacity of protein synthesis in vitro. Low $K_{\mathrm{m}}$ values for tRNA acylation may be important for creating a necessary downhill gradient to promote the intracellular flux of amino acids towards protein synthesis. The intracellular concentration of phenylalanine and methionine will decline within 2 to $4 \mathrm{~h}$ (Table V) unless altered protein synthesis and degradation maintain the concentration above $K_{\mathrm{m}}$ for tRNA charging. If the intracellular pool is not refilled enough at regular intervals, protein synthesis must be supported by amino acids made available by proteolysis, or protein synthesis will be rapidly decreased. A negative protein balance may thus exist at different levels of protein turnover (23-25). This theory does, however, not explain why there should be a concentration threshold for amino acids to be taken up in peripheral tissues. A pull phenomenon due to a down-hill gradient for amino acid uptake across muscle membranes without a threshold phenomenon across the cell membrane could divert amino acids away from vital organs in conditions with low postabsorptive

Table VIII. Multiple Linear Regression Analysis*

\begin{tabular}{lccr}
\hline & $\mathrm{y}$ variable (AV-phe) & & \\
\cline { 2 - 3 } & $\mathrm{x}$ variable (A-phe) & Insulin & Blood flow \\
\hline Intercept & -5.7344 & & \\
Coefficients & 0.1287 & -0.1092 & -1.3560 \\
$t$ value of coefficients & 4.5648 & -0.4715 & -1.3030 \\
SD of coefficients & 0.0282 & -0.2316 & 1.0406
\end{tabular}

$\boldsymbol{R}=\mathbf{0 . 7 8}$ is significantly different from the simple correlation coeffcient $r=0.61(P<0.05)$. The simple regression between AV-phe and A-phe satisfied the equation $y=0.0963 x-8.9000(n=35, P$ $<0.01$ ). The multiple regression coefficient for AV-phe versus A-phe, insulin, and blood flow. $R=0.78 . N=26 . P<0.01$.

* Dependent variable is A-V difference of phenylalanine (AV-phe). Independent variables are arterial concentrations of phenylalanine (A-phe), arterial plasma insulin, and leg blood flow. plasma levels of amino acids. If so, the skeletal muscles could be in serious competition with other tissues and their protein synthesis just by means of the size of the skeletal muscle pool. A threshold gradient across the cell membrane may then prevent this situation from occurring and allow amino acids to be taken up in muscles only in the fed situation.

A lack of uptake or balance of amino acids may be manyfold, such as substrate availability, hormonal millieu, and low physical activity, but the extracellular concentration of amino acids may also be a critical factor (26). We have no reason to believe that lack of energy was a factor of importance in our present experiments. The individuals were well nourished and assumed to have normal glycogen stores. Besides, the infusion of amino acids increased oxygen consumption and gave a net uptake of glucose concomitant with increased efflux of lactate. Previous studies have also demonstrated a consistently negative amino acid balance in traumatized and septic patients on intravenous nutrition (27), and in patients on enteral nutrition (2). It is, however, obvious that it is possible to obtain a net uptake of amino acids across skeletal muscle in normal individuals simply by increasing the infusion rate of amino acids, which leads to increased arterial levels (Table III [28, 29]).

It was recently reported that $80 \%$ of intravenously infused amino acids are taken up across the splanchnic bed when amino acids were given at a constant rate of $0.2 \mathrm{~g}$ amino acids/ $\mathrm{kg}$ per $\mathrm{h}(30)$. In the present study, the peripheral tissue uptake of amino acids was estimated to be $\sim 35 \%$ at our highest infusion rate. The leg disposal of amino acids was $6-8 \%$ (30), which agrees with 6\% in our experiments (Table VII). The fate of such amino acids may either be degradation, protein synthesis, or intracellular accumulation. The results in the present study show that $\sim 10 \%$ of the infused amino acids were immediately oxidized when amino acids were infused at $0.8 \mathrm{~g} \mathrm{~N} / \mathrm{kg}$ per $\mathrm{d}$. This oxidation percentage of infused amino acids is considerably less than the percentage of overall whole body protein oxidation, which is $\sim 30 \%$ as measured by indirect calorimetry. This discrepancy emphasizes that several amino acid pools may not have equilibrated within $6 \mathrm{~h}$ of infusion in spite of steady state in the intravascular compartment. In the skeletal muscle tissue we measured that the intracellular concentration of the branched chain, phenylalanine, and methionine increased significantly already at the lower infusion rate. The precise fate of the amino acids taken up cannot be decided in the present study. Future experimentation may answer the questions of whether such amino acids end up in protein, to what extent individual amino acids are 
oxidized, or whether they are stored in a labile pool intracellularly ready to be mobilized when the amino acid infusion is interrupted.

Multiple regression analysis was performed to evaluate the source of variation in A-V balance of phenylalanine. The arterial concentration of phenylalanine, insulin, and leg blood flow were selected on a theoretical basis as possible factors regulating amino acid balance. The arterial concentration of phenylalanine was the most important factor for phenylalanine uptake within the observed range for insulin levels up to $58 \mu \mathrm{U} / \mathrm{ml}$ and blood flow values within the normal range, from 2.0 to $2.5 \mathrm{ml} / \mathrm{min}$ per $100 \mathrm{~g}$ up to $9 \mathrm{ml} / \mathrm{min}$ per $100 \mathrm{~g}$. Only insulin, and not blood flow, correlated to the A-V differences of phenylalanine in a simple correlation analysis, although the two together contributed significantly to explain the variation in phenylalanine balance in a multifactorial analysis (Table VIII). Insulin and blood flow were not interrelated, but insulin and arterial levels of amino acids were $(P<0.05)$. It has been reported that amino acid uptake by splanchnic and leg tissues is relatively independent of insulin levels (31), although this conclusion was recently questioned (32). $38 \%$ of the variation of phenylalanine balance was thus explained by the arterial concentration alone, while $61 \%$ was explained by the three together $(P<0.05)$. Multiple regressions for tyrosine and methionine gave similar results. The addition of the A-Vdifferences of the branched chain amino acids increased the multiple regression coefficient to 0.91 . This means that $83 \%$ of the uptake of phenylalanine was related to the uptake of the four factors together. This may be interpreted to indicate that the transport of several amino acids is dependent to some degree on the balance of the branched chain.

To summarize, this study provides us with information on amino acid transport kinetics during step-wise increased infusion of a complete amino acid solution used in intravenous nutrition. By the primed constant infusion technique, it was possible to obtain constant arterial concentrations of most of the amino acids. This fact made it possible to evaluate flux of amino acids and to translate such results into transport kinetics for individual amino acids. Estimates of the maximum capacities for protein synthesis in human muscles according to our previous studies and values of tRNA acceptor sites taken from the literature agree in order of magnitude with net uptake of amino acids in vivo in the fed situation as presented in this study: The transport capacity of amino acids was not a limiting step for amino acid uptake across the leg. Future studies are aimed to relate flux of amino acids directly to protein syrithesis in vivo.

\section{Acknowledgments}

This work was supported by grants from the Swedish Cancer Society (project No. 93), the Swedish Medical Research Council (project No. 536), the Swedish Medical Society, and the Gothenburg Medical Society.

\section{References}

1. Bennegård, K., E. Edén, L. Ekman, T. Scherstén, and K. Lundholm. 1983. Metabolic response of whole body and peripheral tissues to enteral nutrition in weight-losing cancer and non-cancer patients. Gastroenterology 85:92-99.
2. Bennegård, K., L. Lindmark, E. Edén, G. Svaninger, and K. Lundholm. 1984. Flux of amino acids across the leg in weight-losing cancer patients. Cancer Res 44:386-393.

3. DeFronzo, R. A., J. D. Tobin, and R. Andres. 1979. Glucose clamp technique, a method for quantifying insulin secretion and resistance. Am. J. Physiol. 237:E214-E223.

4. Abumrad, N. N., D. Rabin, K. L. Wise, and W. W. Lacy. 1982. The disposal of an intravenously administered amino acid load across the human forearm. Metab. Clin. Exp. 31:463-470.

5. Johrfeldt, L., and J. Wahren. 1971. Leg blood flow during exercise in man. Clin. Sci. 41:459-473.

6. Edén, E., L. Ekman, K. Bennegård, L. Lindmark, and K. Lundholm. 1984. Whole body tyrosine flux in relation to energy expenditure in weight-losing cancer patients. Metab. Clin. Exp. 33:1020-1027.

7. Hill, D. W., F. H. Walters, T. D. Wilson, and J: D. Stuart. 1979. High performance liquid chromatographic determination of amino acids in the picomol range. Anal. Chem. 51:1338-1341.

8. Ho, R. J. 1970. Radiochemical assay of long chain fatty acids using $63 \mathrm{Ni}$ as tracer. Anal. Biochem. 36:105-113.

9. Bengtsson, C., B. Hultén, and B. Larsson. 1981. Nya längdvikttabeller för medelålders och äldre män och kvinnor. Läkartidningen. 78:3152-3154.

10. Woolf, C. M. 1968. Principles of Biometry. D. van Nostrand Co., Inc. 70-82.

11. Christensen, H. N. 1982. Interorgan amino acid nutrition. Physiol. Rev. 1193-1233.

12. Abumrad; N. N., and B. Miller. 1983. The physiologic and nutritional significance of plasma-free amino acid levels. J. Parenter. Enteral. Nutr. 7:163-170.

13. Flaim, K. E., D. E. Peavy, W. V. Everson, and L. S. Jefferson. 1982. The role of amino acids in the regulation of protein synthesis in perfused rat liver. J. Biol. Chem. 257:2932-2938.

14. Shenoy, S. T., and Q. R. Rogers. 1977. Effect of starvation on the charging levels of transfer ribonucleic acid and total acceptor capacity in rat liver. Biochim. Biophys. Acta. 476:218-227.

15. Lundholm, K., and T. Scherstén. 1977. Protein synthesis in human skeletal muscle tissue: influence of insulin and amino acids. Eur. J. Clin. Invest. 7:531-536.

16. Lundholm, K., and T. Scherstén. 1975. Leucine incorporation into proteins and cathepsin-D activity in human skeletal muscles. The influence of the age of the subject: Exp. Gerontol. 10:155-159.

17. Lundholm, K., and T. Scherstén. 1975. Determination in vitro of the rate of protein synthesis and degradation in human skeletal muscle tissue. Eur. J: Biochem. 60:181-186.

18. Lundholm, K., and T. Scherstén. 1979. Protein synthesis in isolated human skeletal muscle tissue: evaluation of an experimental model. Clin. Sci. 57:221-223.

19. Lundholm, K., S. Edström, L. Ekman, I. Karlberg, P. Walker, and T. Scherstén. 1981. Protein degradation in human skeletal muscle tissue: the effect of insulin, leucine, amino acids and ions. Clin. Sci. 60:319-326.

20. Pearson, R. L., C. W. Hancer, J. F. Weiss, D. W. Holladay, and A. D. Kelmers. 1973. Preparation of crude transfer RNA and chromatographic purification of five transfer RNAs from calf liver. Biochim. Biophys. Acta. 294:236-249.

21. Tischler, M. E., M. Desautels, and A. L. Goldberg. 1982. Does leucine, leucyl-tRNA, or some metabolite of leucine regulate protein synthesis and degradation in skeletal and cardiac muscle. J. Biol. Chem. 257:1613-1621.

22. Veselovskaya, L. D., N. N. Orlovskaya, T. I: Mnishenko, and M. F. Gulryi. 1984. Isolation and purification of asparagyl- and valyltRNA synthetases from muscles of normal and starved rabbits. Structural features and kinetic parameters. Mol. Biol. (Engl. Transl. Mol. Biol. [Mosc.]). 18:1113-1118.

23. Clowes, G. H. A., Jr., E. Hirsch, B. C. George, L. M. Bigatello, J. E. Mazuski, and C. A. Villee, Jr. 1985. The significance of altered 
protein metabolism regulated by proteolysis inducing factor, the circulating cleavage product of interleukin-1. Ann. Surg. 202:446-458.

24. Sherwing, R. S., R. G. Hendler, and P. Felig. 1975. Effect of ketone infusions on amino acid and nitrogen metabolism in man. $J$. Clin. Invest. 55:1382-1390.

25. Smith, S. R., T. Pozefsky, and M. K. Chhetri. 1974. Nitrogen and amino acid metabolism in adults with protein-calorie malnutrition. Metab. Clin. Exp. 23:603-618.

26. Aoki, T. T., R. J. Finley, and G. F. Cahill, Jr. 1977. The redox state and regulation of amino acid metabolism in man. Biochem. Soc. Symp. 43:17-29.

27. Clowes, G. H. A., Jr., M. Heideman, B. Lindberg, H. T. Randall, E. F. Hirsch, C. J. Cha, and H. Martin. 1980. Effects of parenteral alimentation on amino acid metabolism in septic patients. Surgery. 88:531-542.
28. Wahren, J., P. Felig, and L. Hagenfeldt. 1976. Effect of protein ingestion on splanchnic and leg metabolism in normal man and in patients with diabetes mellitus. J. Clin. Invest. 57:987-999.

29. Aoki, T. T., M. F. Brennan, W. A. Müller, J. S. Soeldner, J. S. Alpert, S. Saltz, R. L. Kaufmann, M. H. Tan, and G. F. Cahill, Jr. 1976. Amino acid levels across normal forearm muscle and splanchnic bed after a protein meal. Am. J. Clin. Nutr. 29:340-350.

30. Gelfand, R. A., M. G. Glickman, R. Jacob, R. S. Sherwin, and R. A. DeFronzo. 1986. Removal of infused amino acids by splanchnic and leg tissues in humans. Am. J. Physiol. 250:E407-E413.

31. Eriksson, L. S., L. Hagenfeldt, P. Felig, and J. Wahren. 1983. Leucine uptake by splanchnic and leg tissue in man: relative independence of insulin levels. Clin. Sci. 65:491-498.

32. Fukagawa, N. K., K. L. Minaker, V. R. Young, and J. W. Rowe. 1986. Insulin dose-dependent reductions in plasma amino acids in man. Am. J. Physiol. 250(Pt. I):E13-E17. 